\title{
Dorset Palaeoeskimo Skin Processing at Phillip's Garden, Port au Choix, Northwestern Newfoundland
}

\author{
M.A.P. RENOUF ${ }^{1}$ and T. BELL ${ }^{2}$
}

(Received 3 April 2007; accepted in revised form 27 June 2007)

\begin{abstract}
This paper examines artifactual and palaeo-limnological evidence of sealskin processing associated with Phillip's Garden, a Dorset Palaeoeskimo site at Port au Choix in northwestern Newfoundland. We propose that harp seals were hunted from Phillip's Garden as much for skins as for meat and fat, and that processing sealskins was the first step in the important activity of making clothes, boots, and other items. We outline the steps and tools involved in sealskin processing throughout the northern circumpolar world, and we identify specialized skin-processing tools in the Phillip's Garden tool assemblage. Sealskin processing is also inferred from pollen and chironomid data from Bass Pond, adjacent to Phillip's Garden. Disturbance across pollen taxa is evident at 2200-1400 cal BP, and anomalous salinity values are evident at 2000-1400 cal BP. We argue that these are connected to Palaeoeskimo activities at the pond, in particular Dorset sealskin soaking and tanning. This study shifts our perception of Dorset activities at Phillip's Garden away from a narrow focus on seal hunting and the site itself and broadens our view to include more of the multiplicity of day-to-day human activities that took place within a larger cultural landscape that included Phillip's Garden and Bass Pond.
\end{abstract}

Key words: Newfoundland, Dorset Palaeoeskimo, Phillip's Garden, sealskin processing, tabular slate tools, palaeo-limnology, cultural landscape

RÉSUMÉ. Cette communication se penche sur des preuves artéfactuelles et paléolimnologiques relatives à la transformation de peaux de phoques associée au jardin Phillip's, un lieu paléo-esquimau dorset de Port au Choix, dans le nord-ouest de Terre-Neuve. Nous laissons entendre que le phoque du Groenland était chassé du jardin Phillip's tant pour sa peau que pour sa viande et sa graisse, et que la transformation des peaux de phoques constituait la première étape de cette activité importante consistant à confectionner des vêtements, des bottes et d'autres articles. Nous faisons mention des étapes et des outils nécessaires à la transformation des peaux de phoques à l'échelle du monde circumpolaire du Nord, et nous décrivons des outils spécialisés de transformation des peaux provenant de l'assemblage d'outils du jardin Phillip's. La transformation des peaux de phoques est également comprise grâce aux données relatives au pollen et aux chironomes de l'étang Bass, adjacent au jardin Phillip's. Il y a un dérangement évident du taxon du pollen entre 2200 et 1400 cal. BP. Par ailleurs, des valeurs de salinité anomales sont évidentes entre 2000 et 1400 cal. BP. Nous soutenons que ces données sont reliées aux activités paléo-esquimaudes ayant eu lieu à l'étang, plus particulièrement les activités de trempe et de tannage des peaux de phoques du dorset. Cette étude fait dévier notre perception des activités du dorset ayant eu lieu au jardin Phillip's, perception qui voulait que seule la chasse au phoque y ait été pratiquée, et nous laisse croire que de multiples activités humaines s'y déroulaient au quotidien dans le plus grand contexte culturel qu'englobait le jardin Phillip's et l'étang Bass.

Mots clés : Terre-Neuve, paléo-esquimau dorset, jardin Phillip's, transformation des peaux de phoques, outils en schiste tabulaire, paléolimnologie, paysage culturel

Traduit pour la revue Arctic par Nicole Giguère.

\section{INTRODUCTION}

Phillip's Garden (EeBi-1) is the largest and most intensively occupied Dorset Palaeoeskimo site identified in Newfoundland (Fig. 1). It comprises a 2 ha meadow ringed by stunted spruce and fir forest, locally called tuckamore, beyond which are peat barrens (Fig. 2). The meadow consists of three main raised terraces; the upper two terraces at $6-11 \mathrm{~m}$ above sea level are covered by a $20-50$ $\mathrm{cm}$ cultural deposit and have shallow oval or rectangular depressions, which are the central areas of substantial dwellings. Sixty-seven of these structures have been identified to date, and it is certain that others have been filled in with post-occupational midden debris, while still others lie within the edge of the advancing tuckamore. The site was occupied for approximately eight centuries. Thirtyfive charcoal-based radiocarbon dates range from 1990 to 1180 cal BP; all dates in this paper are expressed in calibrated calendar years before present (cal BP) at the one-sigma probability range. Twenty-four dwellings and

\footnotetext{
${ }^{1}$ Archaeology Unit, Memorial University of Newfoundland, St. John’s, Newfoundland A1C 5S7, Canada; mapr@mun.ca

2 Department of Geography, Memorial University of Newfoundland, St. John's, Newfoundland A1C 5S7, Canada; tbell@ mun.ca

(C) The Arctic Institute of North America
} 


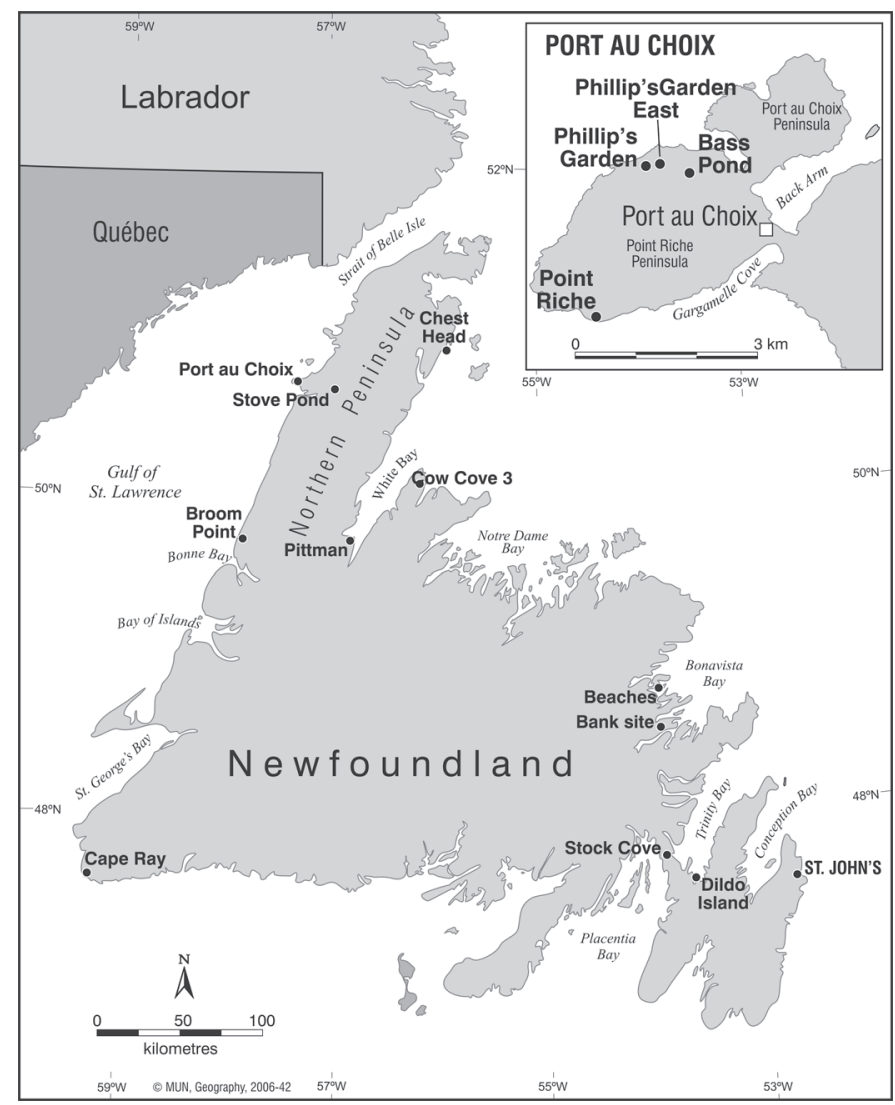

FIG. 1. Place name map, including the location of Dorset sites mentioned in the text and in Table 2. Also shown are Bass Pond and the Groswater Palaeoeskimo site of Phillip's Garden East.

four middens have been excavated or tested by Harp (1964, 1976) and Renouf $(1993,1999,2002,2006)$. On the basis of a per-decade tally of the number of dwellings whose calibrated calendar ages overlap at the one-sigma probability range, site occupation has been divided into three chronological phases that represent an initial low population, followed by a population maximum and a subsequent population decline. The phases are dated at $1990-1550$ cal BP, $1550-1350$ cal BP and 1350-1180 cal BP (Renouf, 2006:122).

Faunal material demonstrates that harp seal hunting was the subsistence basis for the site. The faunal assemblages are predominantly Phocidae, and of those elements that are identifiable to species, over $90 \%$ are Phoca groenlandica, or harp seal (Murray, 1992; Renouf and Murray, 1999; Hodgetts et al., 2003). We therefore assume that most Phocidae bones unidentifiable to species are in fact harp seal. Modern harp seal herds are known to migrate south past the area in December en route to their breeding grounds in the Gulf of St. Lawrence, returning north in April-May (Sergeant, 1992). In December, seals are in open water, whereas in April-May they are associated with the retreating sea ice edge. In the latter period, they occur in an ice lead that regularly opens up not far offshore from Phillip's Garden (LeBlanc, 1996). While April-May exploitation by Dorset is interpreted from the

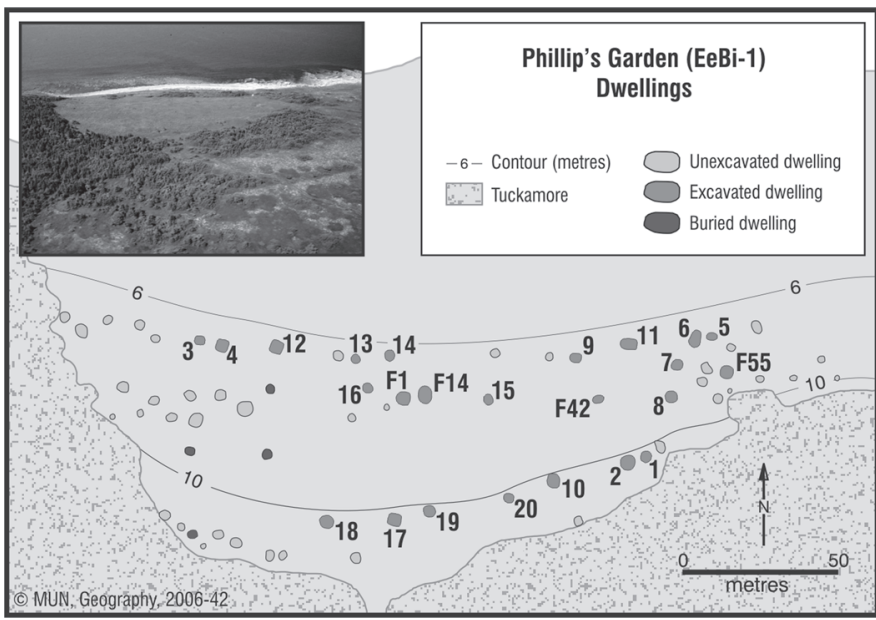

FIG. 2. Phillip's Garden site map, showing dwelling depressions. Numbered ovals refer to dwellings excavated by Harp (and in some cases, re-investigated by Renouf). Ovals prefixed with $\mathrm{F}$ indicate dwelling features excavated by Renouf. Inset photo shows the Phillip's Garden meadow surrounded by tuckamore.

presence of newborn seals (Renouf, 1993), Hodgetts (2005a, b) demonstrated a December exploitation of seals on the basis of the population age profile inferred from femur shaft measurement data. We think that April-May was more likely the main period of harp seal hunting because of the predictability and spatial concentration of seals associated with the ice edge at that time. Hodgetts et al. (2003:113) document changing seal proportions over time. Faunal collections dating from 1930 to $1230 \mathrm{cal} \mathrm{BP}$ show that after 1420 cal BP, there was a decrease in reliance on seal ( $80-70 \%$ of the total identified bones) and a commensurate increase in the proportion of fish and birds $(20-30 \%)$. While this change over time has implications for understanding the eventual abandonment of the site (Renouf and Bell, in press), it shows the sustained importance of seal hunting over the eight centuries of its occupation.

The predictable concentration of harp seals was the basis for a concentration of families at Phillip's Garden. Although we do not know how many of the dwellings were contemporaneous, recent excavations of middle phase dwellings have shown them to be sufficiently large and well constructed to house multiple families over the long term (Renouf, 2006). This suggests that Phillip's Garden was a population aggregation site of the sort common to hunting and gathering people worldwide (Turnbull, 1968; Lee, 1972; Mauss, 1979). Binford (2001:251) summarized the population size at regional aggregation sites of 15 Arctic hunter-gatherer societies, which ranged from 64 to 350 people, with an average of 138 . Given the size and longevity of the dwellings at Phillip's Garden, it is likely that the number of people who gathered for the April-May harp seal hunt was at the higher end of this range.

Seal hunting is reflected in the Phillip's Garden artifact collection. Of the 31067 artifacts, 9.9\% are harpoon endblades. Sealskin processing is an activity complementary to 
TABLE 1. Artifacts from Phillip's Garden database as of 31 December 2006. Counts will change as excavations and collection analyses continue. Radiocarbon dates were calibrated using Calib 5.0 (Stuiver and Reimer, 1993) and dates are from Harp (1976) and the Port au Choix Archaeology Project, including Hodgetts (2002). Dwellings that Harp excavated are given a house number; dwellings that Renouf excavated are given a feature number.

\begin{tabular}{|c|c|c|c|c|c|c|c|}
\hline & \multirow{2}{*}{$\begin{array}{l}\text { Ranges of } \mathrm{C}^{14} \text { Dates Calibrated } \\
\text { to cal } \mathrm{BP} \text { at } 1 \sigma \text { Probability }\end{array}$} & \multirow{2}{*}{$\begin{array}{l}\text { Harpoon } \\
\text { Endblades }\end{array}$} & \multicolumn{3}{|c|}{ Tabular Slate Tools } & \multirow[b]{2}{*}{ Total } & \multirow{2}{*}{$\begin{array}{l}\text { Total No. } \\
\text { of Tools }\end{array}$} \\
\hline & & & Bevelled-Edged & Rounded-Tip & Fragments & & \\
\hline House 1 & undated & 0 & 1 & 0 & 2 & 3 & 90 \\
\hline House 2 & $1710-1340$ & 451 & 47 & 22 & 136 & 205 & 4816 \\
\hline House 3 & undated & 48 & 0 & 0 & 0 & 0 & 229 \\
\hline House 4 & $1520-1410$ & 268 & 33 & 8 & 51 & 92 & 2405 \\
\hline House 5 & $1480-1320$ & 26 & 9 & 1 & 3 & 13 & 222 \\
\hline House 6 & $1600-1420$ & 227 & 22 & 9 & 47 & 78 & 2316 \\
\hline House 7 & undated & 19 & 3 & 1 & 5 & 9 & 154 \\
\hline House 8 & undated & 12 & 0 & 0 & 2 & 2 & 87 \\
\hline House 9 & undated & 4 & 1 & 0 & 2 & 3 & 46 \\
\hline House 10 & $1690-1420$ & 204 & 41 & 4 & 58 & 103 & 2240 \\
\hline House 11 & $1510-1340$ & 301 & 8 & 10 & 68 & 86 & 2445 \\
\hline House 12 & $1520-1370$ & 173 & 16 & 16 & 83 & 115 & 1782 \\
\hline House 13 & undated & 67 & 8 & 3 & 17 & 28 & 510 \\
\hline House 14 & undated & 9 & 0 & 0 & 8 & 8 & 114 \\
\hline House 15 & undated & 20 & 0 & 0 & 5 & 5 & 155 \\
\hline House 16 & $1520-1410$ & 46 & 7 & 1 & 40 & 48 & 661 \\
\hline House 17 & $1390-1310$ & 365 & 42 & 8 & 194 & 244 & 4963 \\
\hline House 18 & $1690-1410$ & 356 & 28 & 4 & 132 & 164 & 3482 \\
\hline House 19 & undated & 34 & 0 & 0 & 4 & 4 & 145 \\
\hline House 20 & $1300-1180$ & 20 & 4 & 0 & 7 & 11 & 271 \\
\hline House Feature 1 & $1920-1630$ & 61 & 8 & 3 & 21 & 32 & 623 \\
\hline House Feature $1 / 14^{1}$ & $\mathrm{n} / \mathrm{a}$ & 20 & 1 & 0 & 1 & 2 & 173 \\
\hline House Feature 14 & $1990-1870$ & 80 & 3 & 2 & 14 & 19 & 807 \\
\hline House Feature 55 & $1410-1180$ & 53 & 4 & 2 & 11 & 17 & 771 \\
\hline Midden Feature 2 & $1990-1340$ & 132 & 18 & 4 & 48 & 70 & 1142 \\
\hline Midden Feature 42 & undated & 35 & 0 & 0 & 6 & 6 & 141 \\
\hline Midden Feature 49 & $1930-1720$ & 5 & 0 & 0 & 3 & 3 & 49 \\
\hline Unknown provenience & & 25 & 0 & 0 & 0 & 0 & 228 \\
\hline Total & & 3061 & 304 & 98 & 968 & 1370 & 31067 \\
\hline
\end{tabular}

${ }^{1}$ From excavation units that could pertain to either house feature.

${ }^{2}$ Total numbers of tools exclude debitage, retouched flakes, and utilized flakes.

seal hunting. In this paper, we argue that tabular slate artifacts, which comprise $4.4 \%$ of the collection (Table 1 ), are specialized sealskin-processing tools. We also argue that changes at 2200-1400 BP in fossil pollen and chironomid assemblages from nearby Bass Pond indicate sealskin depilation and tanning at the pond.

\section{ETHNOGRAPHIC CONTEXT}

In Arctic and Subarctic hunter-gatherer societies, good clothing was essential. Both sealskin and caribou skin were required because of their complementary properties (Oakes and Riewe, 1998). Caribou hair has an open cellular structure that traps air, providing warmth and humidity control; however, it is not waterproof. Seal hair has a more closed cellular structure, so it is not as warm, but the hair has an outer surface of fine overlapping scales that repel water (Meeks and Cartwright, 2005). Thus caribou skin clothing is suited to colder, drier conditions, and sealskin clothing is suited to warmer and wetter weather and is ideal for boots (Bogoras, 1909; Balikci, 1970; Oakes, 1987; Oakes and Riewe, 1998; Meeks and Cartwright, 2005).
Sealskin is thicker and tougher than caribou and is better for tent and kayak covers (Oakes, 1987; Issenman, 1997).

To be made into clothing or other articles, sealskin requires processing that makes it soft and pliable. The following description of the general steps is derived from historical and modern ethnographic literature of northern circumpolar peoples (Boas, 1888; Mason, 1892; Turner, 1894; Nelson, 1899; Jochelson, 1908; Bogoras, 1909; Birket-Smith, 1929, 1945; Jenness, 1946; Holtved, 1967; Igloliorte, 1986; Oakes, 1987; Bock, 1991; Firestone, 1992, 1994; Hall et al., 1994; Thompson, 1994; Issenman, 1997; Oakes and Riewe, 1998; King et al., 2005).

After meat removal, the sealskin had to be cleaned, degreased, stretched, and softened. Further optional steps were depilation and tanning (Issenman, 1997; Oakes, 1987). Oakes (1987:8-10) lists the necessary tools as an $u l u$, a knife sharpener, a straight-edged scraper, a convex-edged scraper, and a scraping platform, commonly a board (Holtved, 1967:126). In the past, scapula and long-bone scrapers were used, and ground slate blades of uluit and scrapers were set into bone or wooden handles (Oakes, 1987; Lemoine, 1997). While bone scrapers are still in use today, $u l u$ and scraper blades today are exclusively metal (Otak, 2005). 
After the seal was flensed, the fat, meat, and connective tissue were removed with a sharp ulu. Oakes (1987) and Rankin and Labrèche (1991:110) describe the edge as unifacial. However, the $u l u$ was multi-purpose, and in other contexts had a bifacial edge (Rankin and Labrèche, 1991; Frink et al., 2003). Long bone and scapula scrapers were commonly used at this stage of the process (Boas, 1888; Birket-Smith, 1929, 1945; Lemoine, 1997). The skin was laid on the woman's thigh or scraping board, and the scraping movements were made away from the body with the bevel of the ulu against the flesh side of the sealskin (Oakes, 1987; Issenman, 1997). Next the skin was scraped with a blunt scraper to press out oil and remove any remaining meat and connective tissue. It was then washed in fresh water, sometimes with the addition of soap, and was pegged out on the ground or lashed to a frame to dry. After drying, the skin was removed from the frame or pegs, rolled up hair side out, and set aside for later processing.

When it was time to prepare the skin, it was unrolled, remoistened, and once again pegged out or lashed to a frame. The flesh side of the skin was scraped with a blunt scraper to break up the connective tissue, thereby stretching and softening the skin. Birket-Smith (1929:242) specifies that a straight scraper was used at this stage. The scraped skin was left to dry, after which it was re-moistened and rescraped; there were several cycles of moistening, scraping, and drying. Commonly the skin was further softened by taking it off the frame or pegs and repeatedly chewing it, wringing it, and stamping on it (Birket-Smith, 1945; Hall et al., 1994). When the skin was sufficiently soft, it was sometimes finished by a final scrape with a sharp scraper or $u l u$ to remove a thin layer of tissue, giving a smooth surface texture (Oakes and Riewe, 1998).

If the sealskin was to be depilated, for use in boot soles, summer waterproof boots, kayak covers or tent covers, the hair was often shaved with a sharp ulu (Turner, 1894; Issenman, 1997). Alternatively, the hair was loosened through putrefaction and then removed with a blunt scraper (Turner, 1894; Nelson, 1899). In this case, a damp skin was rolled, hair side in, sometimes together with a putrefying substance such as fish offal, and left overnight to loosen the hair. Similarly, depilation could be hastened by immersing the skin in hot water (Nelson, 1899; Oakes, 1987; Issenman, 1997) or soaking it in cold water (Bogoras, 1909; Oakes and Riewe, 1998), until the hair began to slip from the follicles and could be more easily scraped off. Hall et al. (1994:22) mention soaking skins in a small pond, where the relatively warm water helped remove the hair, and Boas (1888:112) mentions soaking skins in brooks for the same purpose.

Depilated sealskins were tanned to preserve and waterproof them and to add colour. The tanning solution was commonly a bark-steeped weak brine. A variety of red, black, yellow, orange and brown shades could be produced, depending on which bark or combination of barks was used (Jochelson, 1908; Bogoras, 1909; Oakes and
Riewe, 1998). A favourite was the reddish-brown colour produced by alder (Jochelson, 1908). The scraped and softened sealskin was immersed in the tanning solution for hours or days until it reached the desired colour, after which it was removed and dried.

A similar process is still used by residents of the Northern Peninsula of Newfoundland. They have been making sealskin boots for at least 100 years (Bock, 1991; Great Northern Peninsula Craft Producers, 2002), a practice thought to derive from the Labrador Inuit (Firestone, 1992, 1994). Leather boots were preferred over fur boots because less snow adhered to them (Firestone, 1992). While amongst most circumpolar indigenous groups sealskin scraping was done by women, on the Northern Peninsula it is a man's task. As described by Bock (1991) and the Great Northern Peninsula Craft Producers (2002), seals are hunted in the spring and flensed. The meat and fat are scraped from the sealskin with the sharp blade of a curved knife. The skins are then sprinkled with salt as a preservative and rolled up until the weather gets warmer and the next processing stages can begin. In early summer, the skins are taken out, rinsed, trimmed, and laced into a frame. They are rubbed with sawdust to absorb grease, after which they undergo a process of repetitive scrapings on the flesh side with a blunt iron scraper; the working edge is at a right angle to the skin surface. This stretches and softens the skin and squeezes out the remaining oils in preparation for even absorption of the tanning solution. The frames are placed in the sun to dry for about two weeks and are scraped twice daily. The framed skins are then immersed in a small, shallow, freshwater pond that has warmed up sufficiently to promote bacterial action (Fig. 3). Rocks are placed on the skins to submerge them evenly. The skins are soaked for three to four weeks, during which time bacteria remove or loosen the hair. When the skins are taken out of the pond, they are scraped several times to completely remove the loosened hair. Then they are unlaced from the frames, scraped again, and set aside for tanning.

The tanning solution is a weak brine in which bark had been steeped; the ratio of salt to water is $1: 100$ by volume, and its purpose is to fix the colour. The bark of fir (which produces yellow) and birch (which produces dark red) are used in combination to give the desired hue. The bark is soaked in the solution for two to eight weeks and removed. Then the sealskins are added to the tanning solution and soaked for seven to ten days. When a skin is removed from the tanning solution, it is laced back into the frame for a day to dry, after which it is removed and ready to be made into boots.

To summarize, skin processing required two essential kinds of tools: cutters and scrapers. The cutting tool (usually an $u l u$ ) had a sharp blade for the initial removal of meat, fat, and fibre and also for a final finish if desired; it could be used in skin depilation. Scrapers were both straight-edged and convex-edged and were used to stretch and soften the skin and press out grease. Skin depilation, if required, could be achieved in three ways: (1) shaving 


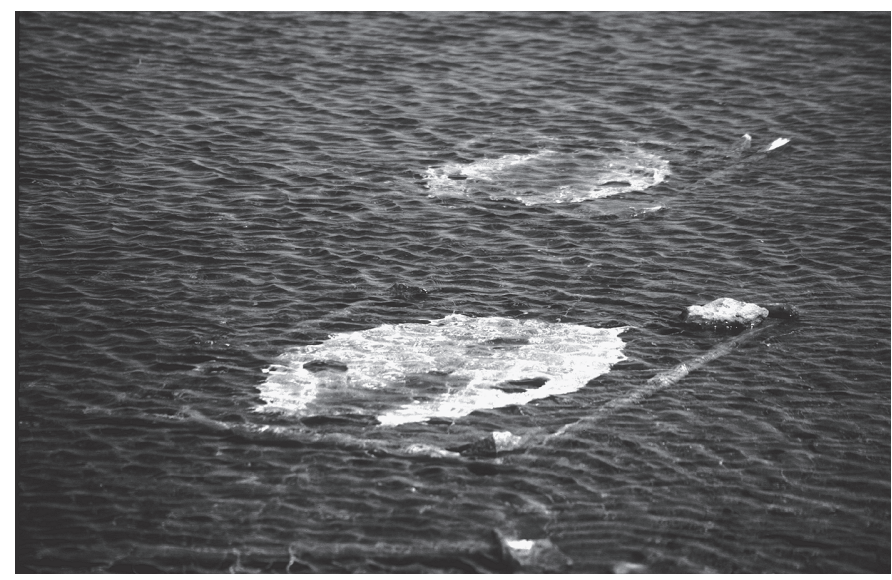

FIG. 3. Framed sealskins soaking in a pond $90 \mathrm{~km}$ north of Port au Choix, in early summer 2000 .

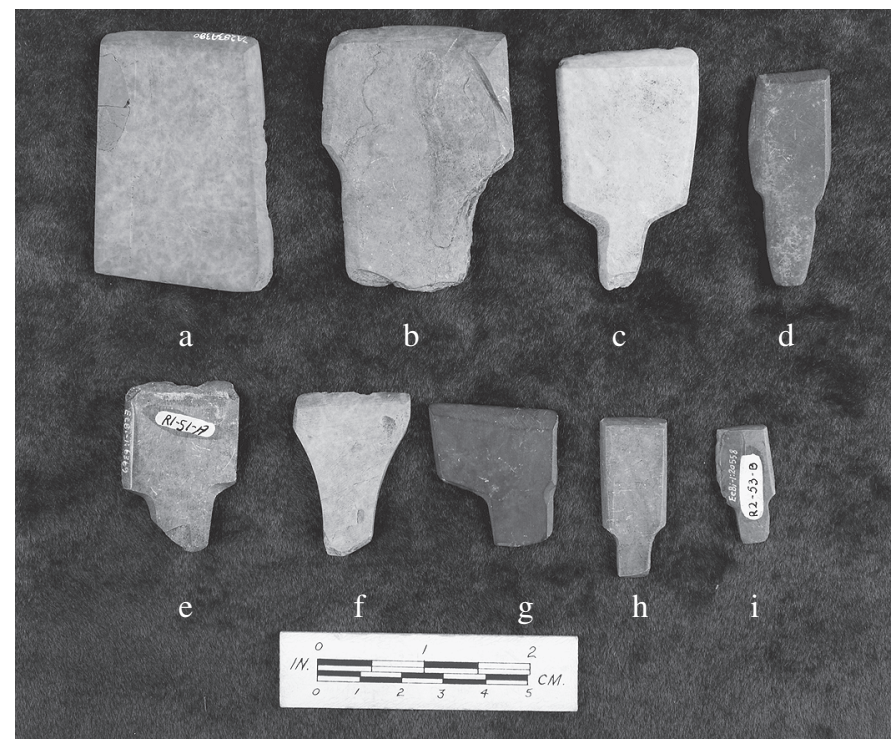

FIG. 4. Bevelled-edged slate tools from Phillip's Garden, representing the range of variation of these tools in the site artifact collection.

with the sharp $u l u,(2)$ scraping with a blunt scraper after the hair was loosened through putrefaction or soaking in hot or cold water, or (3) prolonged soaking in a small, shallow pond to let bacterial action remove or loosen the hair. Depilated skins were tanned using a saltwater solution in which bark had been steeped, with coloration and hue controlled through the combination of tree species used and the duration of immersion.

\section{SEALSKIN PROCESSING AT PHILLIP'S GARDEN}

The 31067 lithic and organic artifacts from Phillip's Garden come from 13 fully excavated and 11 partially excavated dwellings and a number of large and small midden deposits. A total of 1370 tabular slate tools are included in the Phillip's Garden artifact collection (Table 1); the slate source is unknown. Two subcategories are identified: (1) bevelled-edge (Fig. 4) and (2) rounded-tip (Fig. 5). There is

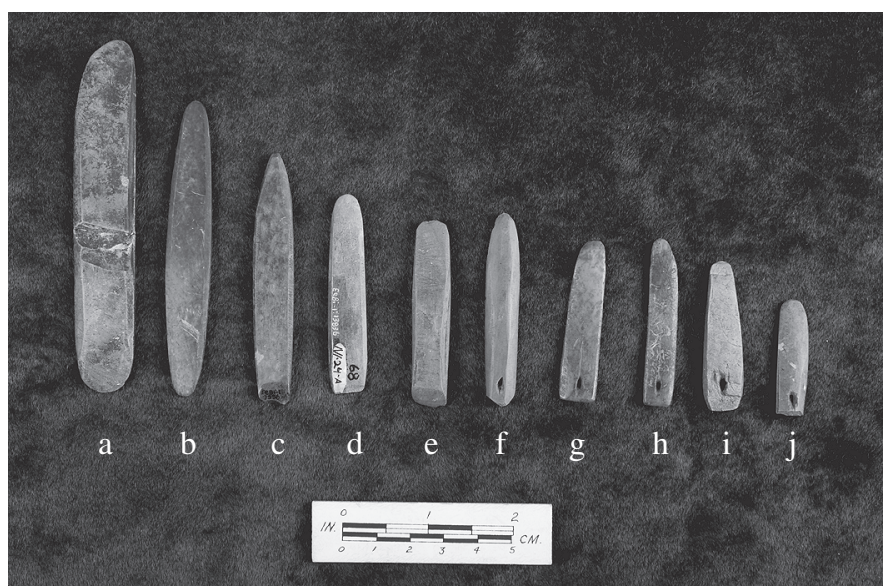

FIG. 5. Rounded-tip slate tools from Phillip's Garden, with the exception of g and $h$, which are ivory. This photo shows the range of variation of these tools in the site artifact collection.

a wide range of variation in size and shape within each subcategory, and there are preforms of both. Many specimens cannot be identified beyond "tabular slate tool fragment" $(\mathrm{n}=968)$ (Fig. 6). This identification is made on the basis of the presence of at least one of the following criteria: (1) one or two flat surfaces; (2) characteristic surface grooves or striations, or both; (3) the presence of one or more holes; and (4) at least one edge that is unifacially bevelled, rounded, blunted, bifacially bevelled and blunted with a third facet, or has a narrow longitudinal ridge. Therefore, although these fragments cannot be identified as bevelled edge or roundedtip, they can be recognized as tabular slate tools and are included in the total. The only other slate tools present in the Phillip's Garden collection are slate points, of which there are 18. While it is possible that some of the smaller ground slate fragments have been misidentified as tabular and are in fact fragments of slate points, this would not change the high proportion of tabular slate tools in the site assemblage.

\section{Bevelled-Edge Tabular Slate Tools}

There are 304 specimens in this subcategory, which includes rectangular forms with flat dorsal and ventral surfaces and one or more straight, unifacially bevelled working edges (Fig. 4). Sometimes two working edges occur as a set of reverse bevels, that is, opposite edges have bevels on opposite surfaces, so that when one edge becomes blunt, the tool can be flipped over to make a sharp edge available. A single tool may even have two sets of reverse bevels (Fig. 4a). Stemmed, bevelled-edge tabular slate tools are common and come in a range of sizes and a variety of shapes (Fig. 4). All stemmed examples have a single distal unifacial bevel; lateral margins have a bifacial bevel blunted by a third facet.

Hafting, where it occurs, takes many forms. The stemmed specimens were likely inserted into a handle, and the sides of the stems are blunted to accommodate the haft without damage. A few specimens have a lateral handle (Bell et al., 2005: Fig. 7) that could have been hand-held or possibly 


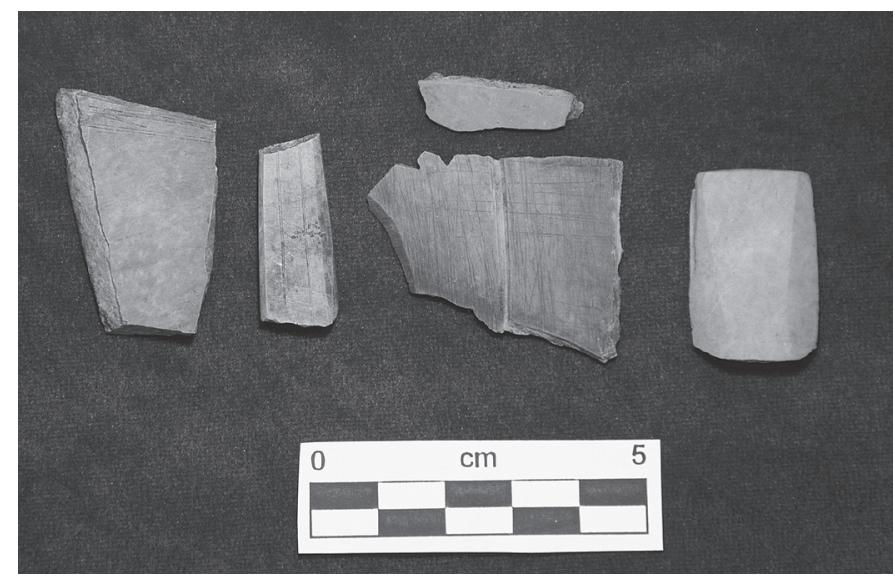

FIG. 6. Tabular slate tool fragments that cannot be identified beyond this general category.

wrapped with sinew to improve the grip. Some stemmed examples have two gouged holes at the proximal margin of the blade, to which a handle would have been lashed or riveted (Fig. 7).

\section{Rounded-Tip Tabular Slate Tools}

There are 98 specimens in this subcategory, which includes linear slate tools that are at least three times as long as they are wide. The dorsal and ventral surfaces are flat, and there is at least one rounded end that is ground thin like a dinner knife. Although many are broken roughly in half, there are complete specimens with two rounded ends (Fig. 5a-b) and, less frequently, with one rounded and one straight, unifacially bevelled end (Fig. $5 \mathrm{~d}-\mathrm{e}$ ). In a few cases the end of the tool is pointed rather than rounded (Fig. 5c). Some specimens are perforated for suspension (Fig. $5 \mathrm{f}-\mathrm{j}$ ). In all cases the lateral margins are rounded or otherwise blunted. In many examples, a narrow ridge runs the full length of the lateral margins, a remnant of the groove-and-snap technique by which they were made. There are a few ivory examples (Fig. $5 \mathrm{~g}-\mathrm{h}$ ) which are not included in the tabular slate subcategory but which probably had a similar function.

\section{Whetstones}

There are at least six complete and 38 whetstone fragments, all made of a variety of fine sandstones. There are two kinds of whetstones (Fig. 8), passive (the edge to be sharpened is rubbed against a stationary stone) and active (the stone is rubbed against a stationary edge to be sharpened). The large passive whetstone in Figure 8 has an extensive polished dorsal surface and two narrower sharpening facets on its side; there is a sharpening groove on the dorsal surface. We conclude that the tabular slate tools were sharpened with these whetstones, which might also have been used to grind, polish, and sharpen other tools, such as nephrite burin-like tools (Harp, 1964:Plate 23:710) and adzes (Harp, 1964:Plate 16:7). These whetstones

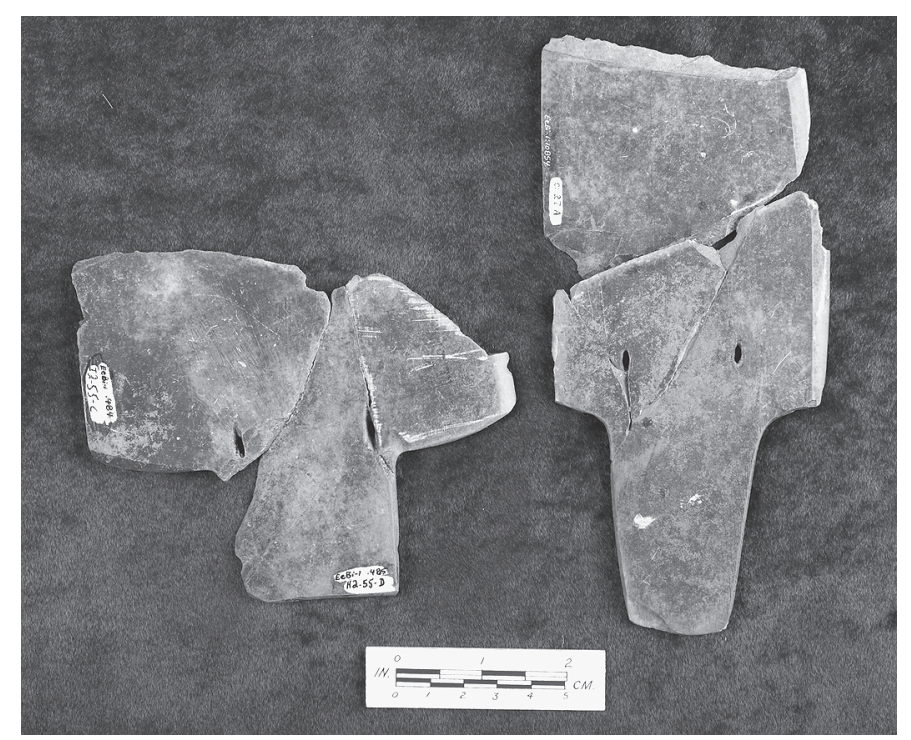

FIG. 7. Hafted, bevelled-edged slate tools from Phillip's Garden.

differ from more common abraders $(n=529)$, which are made of much coarser-grained sandstone and have four to six grinding facets (Harp, 1964:Plate 20:2). These abraders fit the inside angles of the large, rectangular soapstone pots found at the site in fragmentary form, and we therefore assume that they were used to fabricate or clean those pots.

\section{Interpretation}

We propose that the bevelled-edge tabular slate tools are the functional equivalent of the straight-edged and convex-edged scrapers used to stretch, soften, and degrease sealskin. We base this on the unifacial edge bevel, which is appropriate for scraping rather than cutting, and on the fact that slate would be too soft for use with hard materials such as wood, bone, or stone. Harp (1964:63) called these tools bevelled knives and Gracie (2004) identified them as scrapers on the basis of their edge attributes and comparisons with the ethnographic literature. These tools would have required constant re-sharpening, like the slate uluit in replication experiments, which became blunt very easily when used to fillet salmon (Frink et al., 2003). Therefore it must have been useful to have one or two sets of reverse bevels on the bevelled-edge tabular slate tool so that the skin worker could blunt two or four edges before stopping to re-sharpen.

The function of the rounded-tip tabular slate tools is more ambiguous. Harp (1964:64-65) called them flatbladed chisels, and Cox $(1978: 107)$ called them spatulate tools. We can suggest two possibilities, associated not with skin scraping but with the subsequent steps in the transformation of sealskin into clothing and boots. The rounded tip is the right shape to crimp pleats to form the rounded heel and toe of a sealskin boot. Similar tools are called boot-creasers or boot-pressers in the ethnographic literature (Birket-Smith, 1945:116; Oakes and Riewe, 


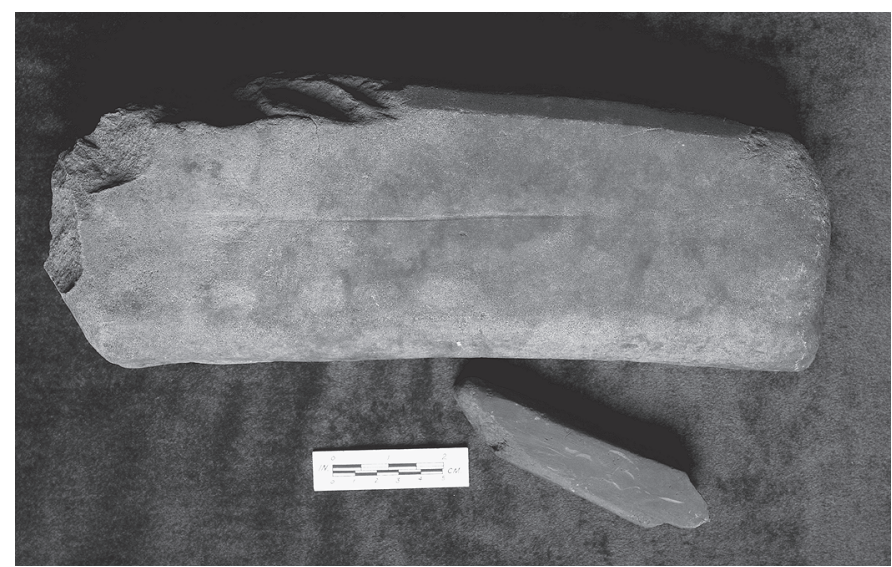

FIG. 8. Large passive and small active whetstones from Phillip's Garden.

1998:16) and are described as small, flat, sharp-edged ivory knives (Nelson, 1899:108; Bogoras, 1909:248). Inuit boot-creasers were traditionally bone or ivory, and some modern versions are metal pliers (Harcharek, 2005) and metal awls (Bock, 1991); Dorset versions might have been slate. The rounded tip of these tools is also the right shape for separating sinew into thread; the tools are similar to the flat or pointed bone or ivory tool called a marlin spike in the ethnographic literature (Murdoch, 1892:292).

\section{SEALSKIN PROCESSING AT BASS POND}

Bass Pond is a small, shallow lake located 500 m east of Phillip's Garden (Fig. 1). It was originally studied to retrieve pollen and oxygen isotope data to reconstruct climate records against which to correlate the occupation history of Phillip's Garden and other Port au Choix sites (Macpherson, 1995). Subsequent studies of chironomids from the lake sediments generated 9000-year records of July water temperature and salinity, which were used to demonstrate rough correspondence between palaeoclimate changes and local culture history (Rosenberg et al., 2005). Pollen analysis of lake sediments revealed distinct records of vegetation and soil disturbance at 2200-1400 cal BP. Subsequent higher-resolution pollen analysis and radiocarbon dating of Bass Pond sediments confirmed these results and provided more detail on the nature and timing of disturbance events (Fig. 9), described in Bell at al. (2005). Analysis of sediment from a second lake, Stove Pond, $11 \mathrm{~km}$ inland of Port au Choix and far from any known archaeological site (Fig. 1), generated baseline observations for comparison with those of Bass Pond (Bell at al., 2005).

Before 3000 cal BP, the curves for the major taxa in Bass Pond sediments show few fluctuations, suggesting no marked changes in the vegetation of the catchment (Fig. 9). At 3000 cal BP, spruce (Picea) pollen reaches a maximum, while fir (Abies) pollen steadily increases, indicating established conifer woodland on the peninsula. Soon after 3000 cal BP, spruce pollen gradually declines until an abrupt decrease at 2200 cal BP. Fir pollen percentages do not mirror this decline, but they do register a marked decrease at $2200 \mathrm{cal}$ BP. Why the spruce component of the woodland selectively declined after $3000 \mathrm{cal}$ BP is not apparent, but since this same decline is not seen in the Stove Pond record, we conclude that it is unrelated to climate.

Another anomaly that appears in this part of the pollen record and is particularly pronounced between 2200 and $1600 \mathrm{cal} \mathrm{BP}$ is the increase in birch (Betula) tree pollen. Birch trees are not common today in the harsh coastal environment of the Point Riche Peninsula and were probably less common during the cooler period between 3000 and 2000 cal BP (Rosenberg et al., 2005). The pollen identified as tree birch is more likely shrub birch; the misidentification relates to the overlap in grain diameter, which is the only basis for their differentiation in Newfoundland pollen records (Dyer, 1986).

There is a prominent charcoal peak at 2200 cal BP. Since there is no corresponding peak at Stove Pond, we interpret this to represent a local forest fire that could in part account for the marked decline in spruce and fir and a corresponding increase in shrubs and herbs. Although the fire could have been natural, we think it more likely that it was started by humans, since the modern-day occurrence of fire on these northern coastal barrens is extremely rare (Meades and Moores, 1989) and the charcoal peak occurred during a particularly cold and wet period, indicated by summer water temperatures in Bass Pond (Rosenberg et al., 2005) and the onset of regional paludification (Davis, 1984).

There is a rapid accumulation of sediment at 2200$1100 \mathrm{cal}$ BP (40-10 $\mathrm{cm}$ depth below core surface) and particularly at $2200-2000 \mathrm{cal} \mathrm{BP}(40-30 \mathrm{~cm})$. This may reflect soil disturbance through loss of protective vegetation cover following the forest fire at $2200 \mathrm{cal}$ BP or increased human activity in the drainage basin, or both.

There were prominent bands of tiny twig fragments, mostly balsam fir, at $29-22 \mathrm{~cm}$ and $40-60 \mathrm{~cm}$ below core surface. The former interval is approximately dated to $2000-1700 \mathrm{cal}$ BP. Although the size of the twigs is too small to see any tool marks, or to require tool use, we do not think this is a natural phenomenon and is more likely anthropogenic.

Although pollen from most shrub and herb taxa showed short-lived peaks in the 2200-2000 cal BP interval, willow (Salix) pollen decreased in abundance, and moss (Sphagnum) spores were reduced to very low levels at $2200-1800$ cal BP. Because willow and moss occur only close to the pond, we conclude that there was disturbance of the vegetation at the pond shore.

Pollen from the aquatic herb Myriophyllum first appeared at $2200 \mathrm{cal} \mathrm{BP}$ and briefly peaked at $2000 \mathrm{cal} \mathrm{BP}$. It subsequently decreased in abundance and disappeared by $1800 \mathrm{cal}$ BP. Myriophyllum occurs today only in eutrophic (nutrient-rich) lakes within the region (Bouchard et al., 1978), indicating similar nutrient enrichment at Bass Pond. 


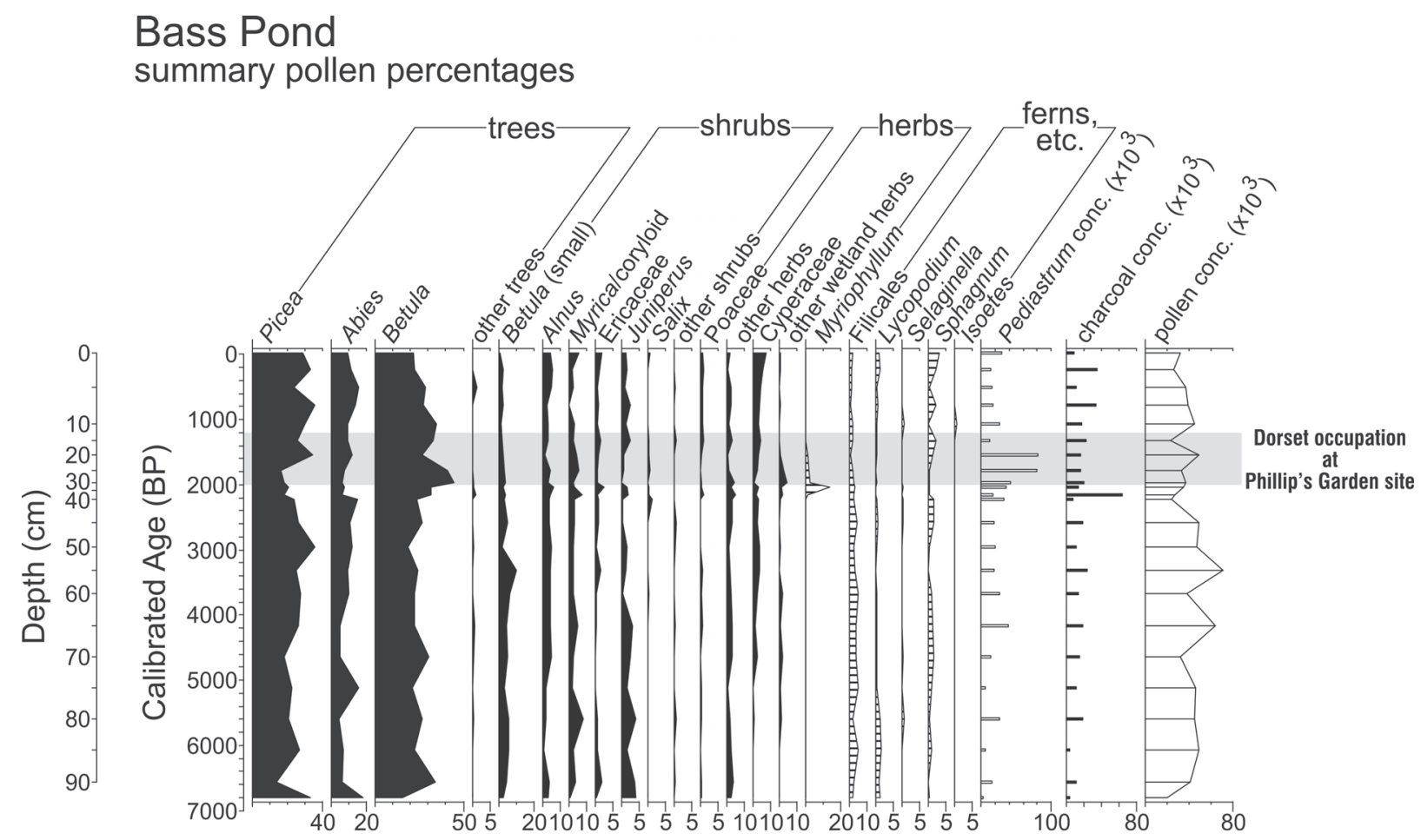

FIG. 9. Bass Pond pollen diagram. The shaded area represents the period of Dorset occupation at Phillip's Garden. The principal y-axis shows the age of the sediment in Bass Pond, derived from five radiocarbon dates on terrestrial macrofossils (Bell et al., 2005). The secondary y-axis (far left) shows sediment depth; variations in the scale between 10 and $40 \mathrm{~cm}$ depth indicate an increase in the rate of sediment accumulation.

There is a coincident and more sustained increase in remains of the aquatic alga Pediastrum at $2000-1400 \mathrm{cal} \mathrm{BP}$, which also indicates nutrient enrichment of Bass Pond waters.

Fossil chironomid assemblages from the Bass Pond core (not shown on Fig. 9) indicate a dramatic rise in salinity from 0.1 to $1.9 \mathrm{~g} / \mathrm{l}$ after $2200 \mathrm{cal} \mathrm{BP}$, peaking at $2000 \mathrm{cal} \mathrm{BP}$ and then declining to $0.8 \mathrm{~g} / \mathrm{l}$ by $1800 \mathrm{cal} \mathrm{BP}$. Elevated salinity levels continued until $1400 \mathrm{cal} \mathrm{BP}$, and freshwater conditions did not return to Bass Pond until 1100 cal BP (Rosenberg et al., 2005).

\section{Interpretation}

We propose that the disturbance across a number of pollen taxa at 2200-1400 cal BP and the increase in salinity at 2000-1400 cal BP are related to the Palaeoeskimo occupation of the Bass Pond region, in particular the intensive Dorset occupation of Phillip's Garden during 1990-1180 cal BP. However, some of the early disturbance from 3000 to 2200 cal BP may be attributable to the smaller-scale Groswater Palaeoeskimo occupation of the Phillip's Garden East site that lies between Phillips Garden and Bass Pond (Fig. 1) and dates to 2950-2130 cal BP (Renouf, 2005). Phillip's Garden East is a small site $\left(1500 \mathrm{~m}^{2}\right)$ that is interpreted as a shortterm, seasonal, harp seal-hunting occupation involving a small residential group (Kennett, 1990; Renouf, 1994, 2005; LeBlanc, 1996, 2000). It has two spatially and temporally distinct occupation areas (Renouf, 2005), which suggests that occupation was episodic. This contrasts with the continuous occupation of Phillip's Garden by many families who likely stayed at the site for several months each year.

We interpret three kinds of human disturbance. First, we suggest that the Groswater occupation of Phillip's Garden East caused the gradual reduction in spruce trees in the local coniferous woodland after $3000 \mathrm{cal} \mathrm{BP}$ and the burning of that woodland seen in the charcoal peak at 2200 cal BP. Groswater people used fire-heated rocks for their main source of heat (Renouf, 1994), and therefore hearths or hot rocks may have caused accidental burning of local forest cover.

Second, lakeside disturbance is reflected in a marked reduction in the occurrence of willow and moss in Bass Pond sediments at $2200-1800 \mathrm{cal} \mathrm{BP}$. We suggest that this reduction is linked to trampling, first by Groswater and later by Dorset people, as they engaged in pond-side activities. Moss is particularly vulnerable to trampling and in this case did not return to pre-disturbance levels until $1400 \mathrm{cal}$ BP, toward the end of the most intensive occupational phase of Phillip's Garden (1550-1350 cal BP).

Third, we propose that the disturbance across Bass Pond pollen taxa at $2200-1400 \mathrm{cal} \mathrm{BP}$ is the result of two separate and sequential processes, those at 2200-2000 cal $\mathrm{BP}$ relating to the forest fire noted above, and those at $2000-1400$ cal BP relating to Dorset sealskin-processing activities. The initial peak of nutrient levels at $2200 \mathrm{cal}$ $\mathrm{BP}$, seen in the appearance of Myriophyllum at this time with a later spike at $2000 \mathrm{cal} \mathrm{BP}$, is likely the result of the forest fire and soil erosion resulting from loss of vegetation; 
fire can release nutrients into catchment soils which can then be leached or eroded into ponds (cf. Cwynar, 1978; Burden et al., 1986). Increased soil erosion is also reflected in the increased sedimentation in the lake basin at $2200-2000$ cal BP. Soon after 2000 cal BP, shrub and herb taxa returned to pre-fire levels. However, tree taxa did not return to normal levels until $1500 \mathrm{cal} \mathrm{BP}$, well after the 2200 cal BP forest fire. Similarly, increased nutrient levels (Pediastrum) persisted until 1400 cal BP. Willow and moss remained low until $1800 \mathrm{cal} \mathrm{BP}$, sedimentation rates remained high until $1100 \mathrm{cal} \mathrm{BP}$, and salinity levels, elevated at $2000-1400 \mathrm{cal} \mathrm{BP}$, did not return to normal until 1100 cal BP.

We propose that these disturbances are related to Dorset sealskin-processing activities. Sealskins were immersed in water for depilation, as in modern Northern Peninsula practices, thus encouraging bacterial growth (identified on the basis of an increase in Pediastrum) and increasing pond-side trampling (identified on the basis of a decrease in Sphagnum and Salix). The increase in salinity is intriguing. Whereas Rosenberg et al. (2005) speculate that this might be the result of a marine incursion or the reworking of marine sediments, an alternative hypothesis is that the increase in salinity is associated with tanning activity that took place near the pond, and that the saline tanning solutions were tipped into the pond after use.

To summarize the comparative chronology of disturbance events and human occupation, the 2200-1400 cal $\mathrm{BP}$ vegetation disturbance in Bass Pond corresponds to the end of the 2950-2130 cal BP Groswater occupation of Phillip's Garden East and to the early (1990 - $1550 \mathrm{cal}$ BP) and middle (1550-1350 cal BP) occupational phases of Phillip's Garden. Bass Pond salinity and sediment accumulation returned to normal just after Phillip's Garden abandonment at $1180 \mathrm{cal} \mathrm{BP}$. While it is reasonable to expect a linear relationship between the occupational intensity at Phillip's Garden and evidence of sealskin processing at Bass Pond, at present this is not evident. Higher resolution archaeological and palaeo-limnological data might be required to assess this expectation.

\section{DISCUSSION}

Current research on Phillip's Garden has focused on harp seal hunting and its associated technology and seasonality and on the large dwellings and community that this activity supported (Harp, 1976; Murray, 1992; Renouf, 1993, 1999, 2002, 2006; Renouf and Murray, 1999; Hodgetts et al., 2003). Harp seals provided not only meat for food and blubber for fuel, but also the essential raw material for making waterproof clothing and other articles without which hunting would not have been possible. A substantial number of seals would have been required to provide one set of waterproof clothing as well as boots, bags, bedding and covers for kayaks and dwellings. Issenman (1997:73) noted that a hunter in Nunavut needed eight ringed seal skins for his spring and summer parka and trousers, not including boots and mitts. Pedersen (2005:70) reported that it took her 12 ringed seal skins to sew one set of clothes for an adult female, including boots and trousers.

Although harp seals are larger than ringed seals, and fewer harp seal skins would be required for a set of clothing, nevertheless the Phillip's Garden Dorset would have required a substantial number of seal skins on a continuing basis. This reinforces our argument that the Phillip's Garden harp seal hunt was for the purpose of obtaining skins as well as blubber and meat.

The focus on sealskin processing at Phillip's Garden is reflected in the proportion of tabular slate tools $(4.4 \%)$. We compared the proportion of ground slate tools from 11 Dorset sites in Newfoundland (Table 2). While it would be desirable to re-examine these collections to establish direct comparability with our Phillip's Garden database, at this preliminary stage we used specimen counts available from theses, reports, and databases; in some cases, we were able to obtain updated information from site excavators. We assume that the counts include complete and incomplete specimens and fragments. Where slate endblades or points were specified (Phillip's Garden, Chest Head, Stock Cove, Beaches, the Bank site; Fig. 1), they were excluded from the counts, but where they are not specified, there is no way of knowing if they are included in the total given for slate artifacts (Table 2). Thus, the slate tool counts from other sites might be inflated in comparison with the total of Phillip's Garden tabular slate tools.

Among this sample of Dorset sites, only three sites have a proportion of slate comparable to that at Phillip's Garden: Cape Ray (4.3\%), Chest Head (3.3\%) and Point Riche (5.6\%) (Fig. 1). Although none of these sites approach the size of Phillip's Garden, they are nevertheless three of the largest Dorset sites in Newfoundland. Like Phillip's Garden, they are situated on prominent headlands and are interpreted as major harp seal hunting sites (Linnamae, 1975; Fogt, 1998; Eastaugh, 2002; Penney and Renouf, 2006). In contrast, the other sites in the sample have fewer than $1.1 \%$ slate tools. All are within protected inner bays, sheltered coves or deep inlets, which are poor harp seal hunting locations. An exception is Broom Point (Fig. 1), which is near important lithic outcrops and is interpreted as a small lithic workshop (Krol, 1986:211). If tabular ground slate tools are specialized sealskin working tools, as proposed, it makes sense that they appear in the greatest numbers at major harp seal hunting sites.

Tabular ground slate tools are largely a Newfoundland phenomenon, although a few specimens have been identified in Labrador sites (Cox, 1978; Jordan, 1986). The published literature indicates some possible functional analogues from eastern Arctic sites. Examples are the straight-tipped, side-notched ground slate knives at the Tanfield site in Lake Harbour (now Kimmirut), southern Baffin Island, which Maxwell (1985:142) suggested were skin scrapers; the rounded-tipped, side-notched slate knives from Nanook, Lake Harbour (Maxwell, 1985); the straight- 
TABLE 2. Relative frequency of ground slate tools from 11 Dorset sites in Newfoundland. The counts exclude debitage, retouched flakes, and utilized flakes.

\begin{tabular}{|c|c|c|c|c|c|c|}
\hline \multirow[b]{2}{*}{ Site Name } & \multirow[b]{2}{*}{ Borden \# } & \multirow[b]{2}{*}{ Location } & \multicolumn{3}{|c|}{ Tools } & \multirow[b]{2}{*}{ Data Source } \\
\hline & & & Slate & Total & $\%$ Slate & \\
\hline Phillip's Garden & EeBi-1 & exposed headland & 1357 & 31067 & 4.37 & PAC Archaeology Project database \\
\hline Point Riche & EeBi-20 & exposed headland & 112 & 1995 & 5.61 & Eastaugh, 2002 \\
\hline Cape Ray & CjBt-1 & exposed headland & 223 & 5142 & 4.34 & Linnamae, 1975; Fogt, 1998 \\
\hline Chest Head & EfAx-2 & exposed headland & 36 & 1101 & 3.27 & PAC Archaeology Project database \\
\hline Broom Point & D1B1-1 & exposed point of land & 0 & 368 & 0 & Krol, 1987 \\
\hline Cow Cove 3 & $\mathrm{EaBa}-16$ & sheltered cove near headland & 2 & 408 & 0.49 & Erwin, 2003, pers. comm. 2007 \\
\hline Dildo Island, House 2 & $\mathrm{CjAj}-2$ & inner bay island & 50 & 4566 & 1.1 & LeBlanc, 2003, pers. comm. 2007 \\
\hline Stock Cove & CkAl-3 & inner bay & 3 & 1091 & 0.27 & Robbins, 1985 \\
\hline Beaches & DeAk-1 & inner bay island & 1 & 322 & 0.31 & Carignan, 1975 \\
\hline Bank Site & DdAk-5 & deep inlet & 0 & 1081 & 0 & Schwarz, 1992 \\
\hline Pittman & DkBe-1 & inner bay headland & 6 & 526 & 1.14 & Linnamae, 1975 \\
\hline
\end{tabular}

tipped and rounded-tipped, side-notched slate tools from Nunguvuk in Navy Board Inlet (Mary-Rousselière, 2002); and the curved-edge slate tool fragment from Saatut in Navy Board Inlet (Mary-Rousselière, 2002). However, it seems that nowhere is there a parallel to the tabular slate tools from Phillip's Garden and other Newfoundland seal hunting sites. This phenomenon is likely connected to the large and predictable harp seal herds that are available in Newfoundland. In Labrador accessibility is less predictable since the migrating harp seal herds are at the ice edge, which can sometimes be very far offshore. Elsewhere in the Arctic, people relied more on the solitary ringed seal, whose location can be predicted only generally. Like the rich salmon runs of coastal Alaska and British Columbia, the predictable harp seal concentrations in Newfoundland presented opportunities for optimization of yield through coordinated and concentrated efforts of hunters and processors. The two- and four-sided bevelled-edged slate scrapers from Phillip's Garden would have maximized efficiency in a context of such intensive processing effort.

There are fewer comparisons to be made with our data from Bass Pond. Ekdahl et al. (2004) showed increased eutrophication of Crawford Lake, southern Ontario, near an Iroquoian village dating to the 13 th -15 th century AD. They argued that increased algal production and changes in diatom assemblages in lake sediments at the time of initial Iroquoian occupation were the result of increased nutrient input due to horticultural activity; these changes intensified as subsequent Iroquoian occupation expanded. They concluded that prehistoric populations had a significant and lasting influence on lake ecology (Ekdahl et al., 2004:748). A closer comparison is the study of changes in pond ecology adjacent to PaJa-13, a 13th-15th century AD Thule site in Hazard Inlet, Somerset Island (Douglas et al., 2004). Contemporaneous with site occupation was an increase in pond nutrients, as indicated by the relative frequency of three key diatom species. Pond sediments also showed an anomalous increase in stable nitrogen content. Both disruptions were linked to decay of whale carcasses associated with Thule whale hunting. Douglas et al. (2004:1616) commented that this is the earliest North
American example of human populations affecting freshwater ecology. Our Bass Pond data push evidence of anthropogenic disturbance back to 2200-1400 cal BP.

The archaeological and palaeo-limnological evidence for sealskin processing directs our attention to what Dobres and Hoffman (1994:247) called the micro-scale processes of day-to-day life. Circumpolar ethnography details how sealskin processing was commonly the domain of women, although in some Siberian groups both men and women processed skins (Bogoras, 1909; Oakes and Riewe, 1998), and on the Northern Peninsula, the men turned sealskins into leather (Great Northern Peninsula Craft Producers, 2002). But in Inuit contexts, skin working knowledge and skills were taught to young girls (Freeman, 1978; Harcharek, 2005). Sealskin-processing tools were part of a woman's personal property, and her uluit were part of her identity (Mason, 1892; Rankin and Labrèche, 1991). We do not know if sealskin processing was a female activity in Dorset society, but if it was, then the study of Dorset sealskin processing is the study of the day-to-day activities of women and young girls and, less tangibly, of the expression of their gender and identity.

The archaeological and palaeo-limnological evidence also directs our attention outward from Phillip's Garden to the surrounding area that comprised the day-to-day cultural landscape of its inhabitants. Evidence of human activity at Bass Pond encourages us to see Phillip's Garden in the context of other locations and the pathways that connected them. In their research on concepts of land tenure among historic Amerindian groups, Zedeño et al. (1997) identify landmarks: places where human activities occurred and which therefore have cultural significance. They define the cultural landscape as the network of relations amongst landmarks. Following this approach, Phillip's Garden and Bass Pond were two of the no doubt many landmarks that comprised the cultural landscape within which generations of Dorset families carried out their daily activities on the Point Riche Peninsula. 


\section{CONCLUSIONS}

In summary, we propose that harp seals were hunted from Phillip's Garden for skins, as well as for meat and fat. Processing the skins was the first step in the important activity of making clothes, boots, and items such as bags, bedding, tent covers, and kayak covers. We outline the steps and tools involved in processing sealskin throughout the northern circumpolar world and identify specialized skin-processing tools in the Phillip's Garden tool assemblage. Sealskin processing is also inferred from pollen and chironomid data from nearby Bass Pond, where disturbance across pollen taxa is evident at 2200-1400 cal BP and anomalous salinity values are evident at 2000-1400 cal BP. While it appears that Groswater activities were responsible for some of the disturbances in the pond, particularly those relating to a forest fire and consequent changes in vegetation, we argue that Dorset sealskinprocessing activities carried out from the large Phillip's Garden site were responsible for much of the disturbance. This study shifts our perception of Dorset activities at Phillip's Garden away from a narrow focus on seal hunting and the site itself and broadens our view to include more of the multiplicity of day-to-day human activities that took place within a larger cultural landscape that included Phillip's Garden and Bass Pond.

\section{ACKNOWLEDGEMENTS}

Multi-year funding for the Northern Peninsula Archaeology and Landscape History Project, of which the Port au Choix Archaeology Project is a part, has been provided by SSHRC, NSERC, Parks Canada, the Canada Research Chairs Program, Memorial University of Newfoundland and the Provincial Archaeology Office. Joyce Macpherson and Peter Scott, Memorial University of Newfoundland, identified fossil pollen and wood samples, respectively. We would like to thank Patty Wells and Dominique Lavers, who re-catalogued the Phillip's Garden artifact collection. David Mercer and Charlie Conway of the Memorial University Cartography Lab drafted the diagrams, and Chris Hammond of Memorial University Photography took most of the artifact photographs. We acknowledge discussions with Joyce Macpherson, Marianne Douglas, and Pat Sutherland, and we thank Sylvie LeBlanc and John Erwin for allowing us to use their unpublished data. Thanks also to reviewers of this paper for their helpful comments.

\section{REFERENCES}

BALIKCI, A. 1970. The Netsilik Eskimo. Prospect Heights, Illinois: Waveland Press.

BELL, T., MACPHERSON, J.B., and RENOUF, M.A.P. 2005. Late prehistoric impact on Bass Pond, Port au Choix. Newfoundland and Labrador Studies 20(1):107-129.

BINFORD, L.R. 2001. Constructing frames of reference: An analytical method for archaeological theory building using hunter-gatherer and environmental datasets. Berkeley: University of California Press.

BIRKET-SMITH, K. 1929. The Caribou Eskimos: Material and social life and their cultural position. Report of the Fifth Thule Expedition 1921-1924, Vol. 5. Copenhagen: Gyldendalske Boghandel Nordisk Forlag.

- 1945. Ethnographical collections from the Northwest Passage. Report of the Fifth Thule Expedition 1921-1924, Vol. 6(2). Copenhagen: Gyldendalske Boghandel Nordisk Forlag.

BOAS, F. 1888. The Central Eskimo. Sixth Annual Report of the Bureau of Ethnography. Washington, D.C.: Smithsonian Institution.

BOCK, A. 1991. Out of necessity: The story of sealskin boots in the Strait of Belle Isle. St. Anthony, Newfoundland: Peninsula Typesetting and Design.

BOGORAS, W. 1909. The Chukchee. Memoirs of the American Museum of Natural History, 11.

BOUCHARD, A., HAY, S., and ROULEAU, E. 1978. The vascular flora of St. Barbe South District, Newfoundland: An interpretation based on biophysiographic areas. Rhodora 80:228-308.

BURDEN, E.T., McANDREWS, J.H., and NORRIS, G. 1986. Palynology of Indian and European forest clearance and farming in lake sediment cores from Awenda Provincial Park, Ontario. Canadian Journal of Earth Sciences 23:43-54.

CARIGNAN, P. 1975. The Beaches: A multi-component habitation site in Bonavista Bay. Mercury Series, Paper 39. Ottawa: National Museums of Canada, Archaeological Survey of Canada.

COX, S.L. 1978. Palaeo-eskimo occupations of the north Labrador coast. Arctic Anthropology 15(2):96-118.

CWYNAR, L.C. 1978. Recent history of fire and vegetation from laminated sediments of Greenleaf Lake, Algonquin Park, Ontario. Canadian Journal of Botany 56:10-21.

DAVIS, A.M. 1984. Ombrotrophic peatlands in Newfoundland, Canada: Their origins, development and trans-Atlantic affinities. Chemical Geology 44:287-309.

DOBRES, M., and HOFFMAN, C.R. 1994. Social agency and the dynamics of prehistoric technology. Journal of Archaeological Method and Theory 1(3):211-258.

DOUGLAS, M.S.V., SMOL, J.P., SAVELLE, J.M., and BLAIS, J.M. 2004. Prehistoric Inuit whalers affected Arctic freshwater ecosystems. Proceedings of the National Academy of Science 101(6):1613-1617.

DYER, A.K. 1986. A palynological investigation of the Late Quaternary vegetational history of Baie Verte Peninsula, northcentral Newfoundland. MSc thesis, Department of Geography, Memorial University of Newfoundland, St. John's, Newfoundland.

EASTAUGH, E.J.E. 2002. Intra-site variability at the Dorset site of Point Riche, Port au Choix, MA thesis, Department of Anthropology, Memorial University of Newfoundland, St. John's, Newfoundland.

EKDAHL, E.J., TERANES, J.L., TURTON, C.L., McANDREWS, J.H., and STOERMER, E.F. 2004. Prehistorical record of cultural eutrophication from Crawford Lake, Canada. Geology 32(9):745-748.

ERWIN, J.C. 2003. Interim report for the 2002 field school: The Cow Cove excavations. Unpubl. report on file at the Provincial 
Archaeology Office, Tourism, Culture and Recreation, Government of Newfoundland and Labrador, St. John's, NL A1B 4J6.

FIRESTONE, M. 1992. Inuit derived culture traits in northern Newfoundland. Arctic Anthropology 29(1):112-128.

- 1994. Skin boots, coach boxes and the ski-doo: The renaissance of traditional items in northern Newfoundland. Material Culture 26(2):15-27.

FOGT, L.M. 1998. The excavation and analysis of a Dorset Palaeoeskimo dwelling at Cape Ray, Newfoundland. MA thesis, Department of Anthropology, Memorial University of Newfoundland, St. John's, Newfoundland.

FREEMAN, M.A. 1978. Life amongt the Qallunaat. Edmonton: Hurtig Publishers.

FRINK, L., HOFFMAN, B.W., and SHAW, R.D. 2003. Ulu knife use in western Alaska: A comparative ethnoarchaeological study. Current Anthropology 44(1):116-123.

GRACIE, N. 2004. Function and manufacture of tabular ground slate tools from Phillip's Garden, Newfoundland. Honour's thesis, Department of Anthropology, Memorial University of Newfoundland, St. John's, Newfoundland.

GREAT NORTHERN PENINSULA CRAFT PRODUCERS. 2002. Sealskin craft production and bark tanning. St. Anthony, NL: Multimedia Creations Ltd.

HALL, J., OAKES, J., and QIMMIU'NAAQ WEBSTER, S. 1994. Sanatujut: Pride in women's work: Copper and Caribou Inuit clothing traditions. Hull, Quebec: Canadian Museum of Civilization.

HARCHAREK, J. 2005. Seams of time. In: King, J.C.H., Pauksztat, B., and Storrie, R., eds. Arctic clothing. Montreal: McGillQueens University Press. 28-30.

HARP, E. 1964. The cultural affinities of the Newfoundland Dorset Eskimo. Bulletin 200. Ottawa: National Museum of Canada.

- 1976. Dorset settlement patterns in Newfoundland and southeastern Hudson Bay. In: Maxwell, M.S., ed. Eastern Arctic prehistory: Palaeoeskimo problems. Washington, D.C.: Memoirs for the Society for American Archaeology, No. 31. 119-138.

HODGETTS, L.M. 2002. Report of the 2001 excavations at Phillip's Garden, Port au Choix National Historic Site. Unpubl. report on file at Archaeological Service Centre, Parks Canada, Atlantic Region, Historic Properties, Upper Water Street, Halifax, Nova Scotia B3J 1S9.

. 2005a. Using bone measurements to determine the season of harp seal hunting at Phillip's Garden. Newfoundland and Labrador Studies 20(1):91-106.

- 2005b. Dorset Palaeoeskimo harp seal exploitation at Phillip's Garden (EeBi-1), northwestern Newfoundland. In: Monks, G., ed. The aboriginal exploitation and cultural importance of sea mammals. Oxford: Oxbow Books. 62-76.

HODGETTS, L.M., RENOUF, M.A.P., MURRAY, M.S., HOWSE, L., and BALKWILL, D. 2003. Changing diet breadth at the Dorset Palaeoeskimo site of Phillip's Garden, Newfoundland. Arctic Anthropology 40(1):106-120.

HOLTVED, E. 1967. Contributions to Polar Eskimo ethnography. Meddelelser om Grønland 182(2). Copenhagen: The Commission for Scientific Research in Greenland.
IGLOLIORTE, S. 1986. Skin boots. In: Ennis, F., McMurrich Koop, S., Shiner, S., and Wherry C., eds. A way of life: Traditional skills of Newfoundland and Labrador. St. John's: Jesperson Press. 59-70.

ISSENMAN, B.K. 1997. Sinews of survival: The living legacy of Inuit clothing. Vancouver: University of British Columbia Press. JENNESS, D. 1946. Material culture of the Copper Eskimo. Report of the Canadian Arctic Expedition 1913-1918, Vol. 16. Ottawa: King's Printer.

JOCHELSON, W. 1908. The Jesup North Pacific Expedition: The Koryak. Memoir of the American Museum of Natural History, Vol. 16. New York.

JORDAN, R.H. 1986. Palaeo-eskimos in Atlantic Canada: A regional comparison of Newfoundland and Labrador middle Dorset. In: Palaeo-eskimo cultures in Newfoundland, Labrador and Ungava. Reports in Archaeology 1. St. John's: Memorial University of Newfoundland. 135-150.

KENNETT, B.L. 1990. Phillip's Garden East: A new perspective on Groswater Palaeoeskimos. MA thesis, Department of Anthropology, Memorial University of Newfoundland, St. John's, Newfoundland.

KING, J.C.H., PAUKSZTAT, B., and STORRIE, R., eds. 2005. Arctic clothing. Montreal: McGill-Queens University Press.

KROL, K.F. 1986. Middle Dorset settlement-subsistence patterns in western Newfoundland. MA thesis, Department of Anthropology, Memorial University of Newfoundland, St. John's, Newfoundland.

LeBLANC, S. 1996. A place with a view: Groswater subsistencesettlement patterns in the Gulf of St. Lawrence. MA thesis, Department of Anthropology, Memorial University of Newfoundland, St. John's, Newfoundland.

- 2000. Groswater technological organization: A decisionmaking approach. Arctic Anthropology 37(2):23-37.

—. 2003. A middle Dorset dwelling in Trinity Bay, Newfoundland. Études/Inuit/Studies 27(1-2):493-513.

LEE, R.J. 1972. Intensification of social life among the !Kung Bushmen. In: Spooner, B., ed. Population growth. Cambridge, Massachusetts: The MIT Press. 343-350.

LEMOINE, G.M. 1997. Use wear analysis on bone and antler tools of the Mackenzie Inuit. Oxford: British Archaeological Reports International Series, S679.

LINNAMAE, U. 1975. The Dorset culture. Technical Papers of the Newfoundland Museum 1. St. John's.

MACPHERSON, J.B. 1995. A 6ka BP reconstruction for the island of Newfoundland from a synthesis of Holocene lake-sediment pollen records. Géographie physique et Quaternaire 49(1): $163-182$.

MARY-ROUSSELIÈRE, G. 2002. Nunguvik et Saatut: Sites paléoeskimaux de Navy Board Inlet, Île de Baffin. Mercury Series, Paper 162. Hull, Quebec: Canadian Museum of Civilization. 199 p.

MASON, O.T. 1892. The ulu, or women's knife, of the Eskimo. Washington, D.C.: Smithsonian Institution.

MAUSS, M. 1979. Seasonal variation of the Eskimo: A study in social morphology. London: Routledge and Kegan Paul Ltd.

MAXWELL, M.S. 1985. Prehistory of the eastern Arctic. New York: Academic Press. 
MEADES, W.J., and MOORES, L. 1989. Forest site classification manual: A field guide to the Damman forest types of Newfoundland. St. John's: Ministry of Supply and Services Canada, and Newfoundland Department of Forestry and Agriculture.

MEEKS, N.D., and CARTWRIGHT, C.R. 2005. Caribou and seal hair: Examination by scanning electron microscopy. In: King, J.C.H., Pauksztat, B., and Storrie, R., eds. Arctic clothing. Montreal: McGill-Queens University Press. 42-44.

MURDOCH, J. 1892. Ethnological results of the Point Barrow Expedition. Ninth Annual Report of the Bureau of Ethnography. Washington, D.C.: Smithsonian Institution.

MURRAY, M.S. 1992. Beyond the laundry list: The analysis of faunal remains from a Dorset dwelling at Phillip's Garden (EeBi-1), Port au Choix, Newfoundland. MA thesis, Department of Anthropology, Memorial University of Newfoundland, St. John's, Newfoundland.

NELSON, E.W. 1899. The Eskimo about Bering Strait. Eighteenth Annual Report of the Bureau of American Ethnology. Washington, D.C.: Smithsonian Institution.

OAKES, J.E. 1987. Factors influencing kamik production in Arctic Bay, Northwest Territories. Canadian Ethnological Service, Mercury Series, Paper 107. Ottawa: National Museums of Canada.

OAKES, J.E., and RIEWE, R. 1998. Spirit of Siberia: Traditional native life, clothing and footwear. Washington, D.C.: Smithsonian Institution Press.

OTAK, L.A. 2005. Caribou-skin preparation in Igloolik, Nunavut. In: King, J.C.H., Pauksztat, B., and Storrie, R., eds. Arctic clothing. Montreal: McGill-Queens University Press. 80-83.

PEDERSEN, K. 2005. Eskimo sewing techniques in relation to contemporary sewing techniques: Seen through a copy of a Qilakitsoq costume. In: King, J.C.H., Pauksztat, B., and Storrie, R., eds. Arctic clothing. Montreal: McGill-Queens University Press. 70-73.

PENNEY, M., and RENOUF, M.A.P. 2006. Report of the 2005 field season at Conche. Unpubl. report on file at the Provincial Archaeology Office, Tourism, Culture and Recreation, Government of Newfoundland and Labrador, St. John's, NL A1B 4J6.

RANKIN, C., and LABRÈCHE, Y. 1991. Traditional ulus and their prehistoric counterparts in the central and eastern Arctic. Études/ Inuit/Studies 15(1):105-130.

RENOUF, M.A.P. 1993. Palaeoeskimo seal hunters at Port au Choix, northwestern Newfoundland. Newfoundland Studies 9(2):185-212.

- 1994. Two transitional sites at Port au Choix, northwestern Newfoundland. In: Morrison, D.A., and Pilon, J.-L., eds. Threads of Arctic prehistory: Papers in honour of William E. Taylor. Archaeological Survey of Canada, Mercury Series, Paper 149. Hull, Quebec: Canadian Museum of Civilization. 165-196.

1999. Ancient cultures, bountiful seas: The story of Port au Choix. St. John's: Historic Sites Association of Newfoundland and Labrador.
2002. Archaeology at Port au Choix: 1990-1992 excavations. Occasional Papers in Northeastern Archaeology, 12. St. John's, Newfoundland: Copetown Press.

2005. Phillip's Garden West: A Newfoundland Groswater variant. In: Sutherland, P.D., ed. Contributions to the study of the Dorset Palaeo-Eskimos. Mercury Series, Archaeology Paper 167. Gatineau, Quebec: Canadian Museum of Civilization. $57-80$.

-2006. Re-investigating a Middle phase Dorset dwelling at Phillip's Garden, Port au Choix, Newfoundland. In: Arneborg, J., and Grønnow, B., eds. Dynamics of northern societies: Proceedings of the SILA/NABO Conference on Arctic and North Atlantic Archaeology, Copenhagen. Studies in Archaeology and History 10. Copenhagen: National Museum. 119-128.

RENOUF, M.A.P., and BELL, T. In press. Precontact population contraction and expansion in Newfoundland, 1200-1000 cal BP. In: Maschner, H., Mason, O., and McGhee, R.J., eds. The northern world AD 1100-1350. Salt Lake City: University of Utah Press.

RENOUF, M.A.P., and MURRAY, M.S. 1999. Two winter dwellings at Phillip's Garden, a Dorset site in northwestern Newfoundland. Arctic Anthropology 36(1-2):118-132.

ROBBINS, D.T. 1985. Stock Cove, Trinity Bay: The Dorset Eskimo occupation of Newfoundland from a southeastern perspective. MA thesis, Department of Anthropology, Memorial University of Newfoundland, St. John's, Newfoundland.

ROSENBERG, S., WALKER, I., and MACPHERSON, J. 2005. Environmental changes at Port au Choix as reconstructed from fossil midges. Newfoundland and Labrador Studies 20(1): $57-73$.

SCHWARZ, F.A. 1992. Archaeological excavations at the Bank Site, Terra Nova National Park, Bonavista Bay, Newfoundland. Unpubl. report on file, Provincial Archaeology Office, Department of Tourism, Culture and Recreation, P.O. Box 8700, St. John's, Newfoundland A1B 4J6.

SERGEANT, D. 1992. Harp seals, man and ice. Canadian Special Publications of Fisheries and Aquatic Sciences 114. Ottawa: Department of Fisheries and Oceans.

STUIVER, M., and REIMER, P.J. 1993. Extended 14C database and revised CALIB radiocarbon calibration program. Radiocarbon 35:215-230.

THOMPSON, J. 1994. From the land: Two hundred years of Dene clothing. Hull, Quebec: Canadian Museum of Civilization.

TURNBULL, C. 1968. The importance of flux in two hunting societies. In: Lee, R.L., and Devore, I., eds. Man the hunter. Chicago: Aldine Publishing. 132-137.

TURNER, L.M. 1894. Ethnology of the Ungava District, Hudson Bay Territory: Indians and Eskimos in the Quebec-Labrador Peninsula. Eleventh report of the Bureau of American Ethnology. Washington, D.C.: Smithsonian Institution.

ZEDEÑO, M.N., AUSTIN, D., and STOFFLE, R.1997. Landmark and landscape: A contextual approach to the management of American Indian resources. Culture and Agriculture 19(3): $123-129$. 